\title{
Plasma Gonadotropins and Estrogens in Girls with Idiopathic Precocious Puberty
}

\author{
F. BIDLINGMAIER, ${ }^{(33)}$ O. BUTENANDT, AND D. KNORR
}

Division of Pediatric Endocrinology, Children's Hospital of the University of Munich, Munich, West Germany

\begin{abstract}
Summary
Luteinizing hormone (LH), follicle-stimulating hormone (FSH) estrone, and estradiol were measured radioimmunologically in more than 60 plasma specimens of 34 girls suffering from idiopathic precocious puberty. Although the median values of both gonadotropins in the plasma of the patients (LH = $1.0 \mathrm{ng}$ ) $\mathrm{ml}$ FSH $=1.6 \mathrm{ng} / \mathrm{ml}$ ) were higher than those from healthy prepubertal girls $(\mathrm{LH}=0.6 \mathrm{ng} / \mathrm{ml}$; FSH $=0.5 \mathrm{ng} / \mathrm{ml})$, only 23 out of $64 \mathrm{LH}$ levels and 30 out of 64 FSH levels exceeded the upper normal limit for age. While the median value of plasma estrone $(13 \mathrm{pg} / \mathrm{ml})$ was found to lie within the normal range for prepubertal girls $(7-29 \mathrm{pg} / \mathrm{ml})$ and only 13 out of 75 estrone values were pathologically elevated, the median value of plasma estradiol $(22 \mathrm{pg} / \mathrm{ml})$ was nearly 3 times higher than the normal median for prepuberty $(8 \mathrm{pg} / \mathrm{ml})$. Of 75 estradiol levels, 35 were above normal for age. Grouping the values according to the stage of sexual development revealed considerably lower gonadotropin and estrogen levels in the patients than in normally maturing girls of the same developmental stage. However, patients who were examined repeatedly at short intervals over a 1 . month period showed an almost cyclic sequence of their estradiol levels similar to the pattern observed in healthy pubertal girls.
\end{abstract}

\section{Speculation}

The findings that plasma estrogens are relatively low in idiopathic precocious puberty in spite of well advanced sexual development suggest that the symptoms of this disturbance do not depend on estrogen concentrations alone. Other factors, such as enhanced receptor sensitivity or changes in the concentration of sexual hormone-binding globulin, must also be taken into consideration.

In the past few years considerable knowledge has been accumulated on plasma estrogens during normal female puberty ( 1 , $3,15,17,29,30)$. However, information is limited regarding these hormones in precocious puberty in girls. We therefore undertook a study of plasma estrone and estradiol and their relationship to the gonadotropins, $\mathrm{LH}$ and $\mathrm{FSH}$, in untreated girls suffering from idiopathic precocious puberty. Our main question was whether gonadotropin and estrogen concentrations and secretion patterns in the patients are comparable with those of healthy girls of the same developmental stage.

\section{MATERIALS AND METHODS}

\section{SUBJECTS AND SAMPLES}

The study was conducted on 34 untreated sexually precocious girls aged from 1 to 9 years. All of them were less than 6 years old when the first symptoms of sexual maturation were noticed. Careful investigation did not reveal any central nervous system or gonadal lesions to explain the premature sexual development. Thus, these patients were considered to suffer from "idiopathic" precocious puberty. In addition to breast development, all of the patients showed other signs of puberty, such as marked bone age acceleration and pubic or axillary hair. In nine cases repeated vaginal bleeding had occurred; however, none of them had regular menstrual cycles. Girls showing only minor symptoms or even spontaneous regression of pubertal development were excluded from this study. The patients were evaluated clinically and grouped into five stages according to their sexual development. As with normal girls, pubertal grouping was based mainly on the criteria of Marshall and Tanner (21) for breast development. All postmenarchal girls were classified as stage 5 (17, 28 ). In some patients repeated gonadotropin and estrogen determinations were performed weekly over a 1 -month period or once every 6 months for up to 3 years. For determination of normal $\mathrm{LH}$ and $\mathrm{FSH}$ values plasma specimens were obtained from 106 healthy girls of all developmental stages. Control values of plasma estrone and estradiol were determined in plasma specimens from 138 healthy females (4). Informed consent was obtained from the subjects studied and/or their parents.

Blood was drawn in heparinized syringes between $9 \mathrm{AM}$ and 3 PM and the plasma was stored at $-20^{\circ}$ until measured. In 64 samples both gonadotropins and estrogens were determined and in 11 additional samples only the estrogens were determined.

\section{LABORATORY METHODS}

Plasma LH and FSH concentrations were measured by a double antibody radioimmunoassay using commercial kits (16). One milligram of FSH corresponded to $169 \pm 19 \mathrm{mg}$ of the human pituitary standard LER $907,1 \mathrm{mg} \mathrm{LH}$ to $66 \pm 6 \mathrm{mg}$ LER 907, respectively. The sensitivity of the method for both $\mathrm{LH}$ and $\mathrm{FSH}$ was $0.05 \mathrm{ng} / 0.1 \mathrm{ml}$ plasma added into the reaction. The interassay variabilities for pooled plasma with a mean concentration of $3.3 \mathrm{ng} / \mathrm{ml} \mathrm{LH}$ and $4.2 \mathrm{ng} / \mathrm{ml} \mathrm{FSH}$ were $8 \%$ and $10.1 \%$, respectively. Concentrations of plasma estrone and estradiol were determined by our own radioimmunologic method, previously described in detail (3). The sensitivity of this method was found to lie at $7 \mathrm{pg} / \mathrm{ml}$ plasma. The coefficients of variation with 10 consecutive assays (determined on a pool of children's plasma) were $10.5 \%$ and $10.9 \%$ for estrone and estradiol, respectively.

\section{RESULTS}

The LH and FSH levels of our patients were compared with those of normal prepubertal girls. In Figure 1 the values are plotted against age regardless of the degree of precocious sexual development. Although the median values of both gonadotropins in the patients $(\mathrm{LH}=1.0 \mathrm{ng} / \mathrm{ml} ; \mathrm{FSH}=1.6 \mathrm{ng} / \mathrm{ml})$ were higher than those of healthy prepubertal girls $(\mathrm{LH}=0.6 \mathrm{ng} / \mathrm{ml}$; FSH $=0.5 \mathrm{ng} / \mathrm{ml}$ ) only 23 out of $64 \mathrm{LH}$ levels and 30 out of 64 FSH levels exceeded the upper normal limit for age.

Similarly, the estrone and estradiol levels of our patients are plotted against age and compared with the normal ranges of healthy female infants and prepubertal girls (Fig. 2). The median value for plasma estrone of $13 \mathrm{pg} / \mathrm{ml}$ was still found in the 
normal range, being barely higher than that of healthy prepubertal girls $(12 \mathrm{pg} / \mathrm{ml})$. Only 13 out of 75 estrone levels were pathologically elevated. However, the median value for plasma estradiol in the patients was $22 \mathrm{pg} / \mathrm{ml}$, almost 3 times higher than the normal median and slightly higher than the upper limit for prepuberty (Table 1). Of 75 estradiol levels, 35 were above normal for the respective age. Repeated testing on the same patients revealed considerable intraindividual fluctuation of the estradiol levels.

Although nearly the same percentage of the FSH levels and the estradiol levels were found to be elevated in the patients with idiopathic precocious puberty, neither a positive nor a negative correlation between these hormones was determined in identical plasma specimens.

Grouping of the plasma LH and FSH values of the sexually precocious girls according to the stage of sexual development and comparison with the corresponding normal ranges (Fig. 3) shows that, with the exception of stage 4 , nearly all LH levels and most of the FSH levels of the patients were in the lower normal range or even below the normal range for healthy girls of the same pubertal stage. Thus, the median values of the plasma

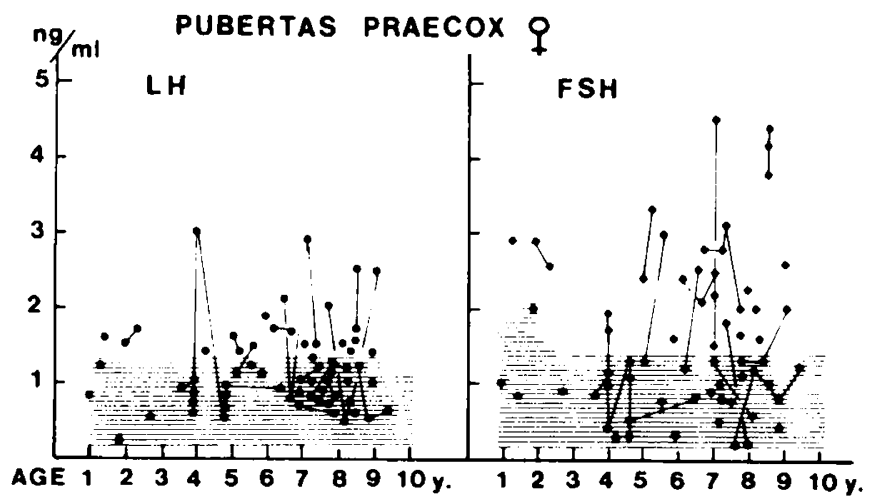

Fig. 1. Plasma luteinizing hormone $(L H)$ and follicle-stimulating hormone $(F S H)$ concentrations in girls with idiopathic precocious puberty plotted against age. The lines join values obtained by serial estimation on the same patient. The shaded areas represent the normal ranges for prepubertal girls. gonadotropins in stages 2,3 , and 5 are lower in the patients than in normally maturing girls (Table 1 ).

A more striking difference becomes evident when the estrogen levels of our patients and those of healthy girls are compared in the same manner (Fig. 4). Only in stage 2, when breast development starts, did we find similar values in both groups and even some higher estradiol levels in the patients. In all other stages of precocious puberty the estrogens, especially estrone, were surprisingly low. Only isolated values were found in the upper normal range. Thus, in spite of advancing sexual development the median values of estradiol in sexually precocious girls showed only a slight increase and the median estrone levels even failed to increase from stage 2 through stage 5 , remaining normal for age (Table 1).

In addition, intraindividual differences between the patterns of estrone and estradiol could be observed when serial estimations on the same patient were done over a period of 4 or 5 weeks. Figure 5 shows two typical test periods in a 4-year-old girl with idiopathic precocity: breast development stage 3 , pubes stage 2 , enlarged uterus, and accelerated bone age. As in normal pubertal girls, estradiol fluctuated markedly between low pre-

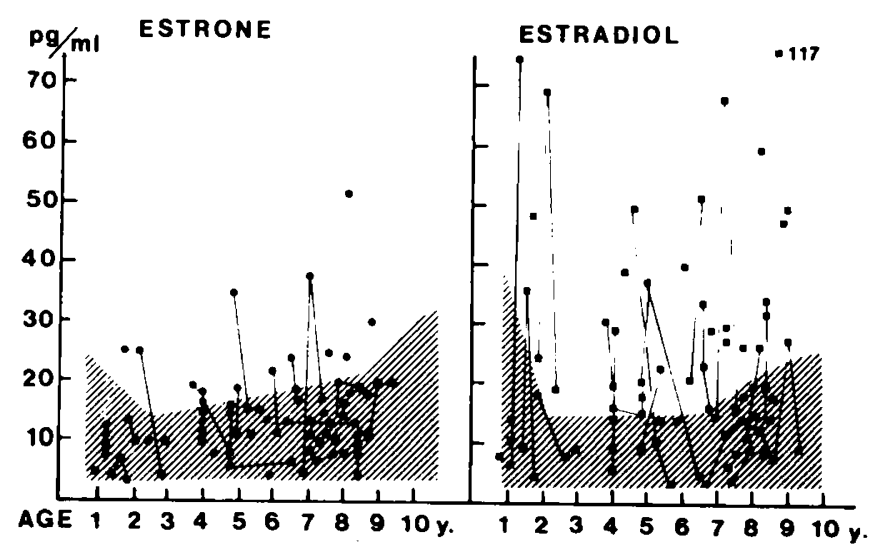

Fig. 2. Plasma estrone and estradiol concentrations in girls with idiopathic precocious puberty plotted against age. The lines join values obtained by serial estimation on the same patient. The shaded areas represent the normal ranges for prepubertal girls.

Table 1. Hormone levels of normal girls and girls suffering from idiopathic precocious puberty

\begin{tabular}{|c|c|c|c|c|c|}
\hline Subjects & Stage $1^{2}$ & 2 & 3 & 4 & 5 \\
\hline \multicolumn{6}{|l|}{$\mathrm{LH}(\mathrm{ng} / \mathrm{ml})$} \\
\hline Normal & 0.6 & 1.1 & 1.6 & 1.6 & 2.0 \\
\hline$n=137^{3}$ & $(<0.5-1.3)$ & $(0.6-2.8)$ & $(0.8-3.0)$ & $(0.5-3.1)$ & $(0.6-3.7)$ \\
\hline Precocious & & 0.8 & 1.0 & 1.6 & 1.4 \\
\hline$n=64$ & & $(0.5-1.7)$ & $(0.7-3.0)$ & $(0.7-2.5)$ & $(0.5-2.5)$ \\
\hline \multicolumn{6}{|l|}{ FSH $(\mathrm{ng} / \mathrm{ml})$} \\
\hline Normal & 0.5 & 1.5 & 2.7 & 3.3 & 2.7 \\
\hline$n=137$ & $(<0.5-1.4)$ & $(0.7-3.0)$ & $(0.6-4.1)$ & $(1.3-5.1)$ & $(1.3-5.6)$ \\
\hline Precocious & & 1.1 & 1.8 & 3.3 & 1.1 \\
\hline$n=64$ & & $(0.5-2.9)$ & $(0.5-4.5)$ & $(2.0-4.4)$ & $(0.5-2.9)$ \\
\hline \multicolumn{6}{|l|}{ Estrone $(\mathrm{pg} / \mathrm{ml})$} \\
\hline Normal & 12 & 16 & 29 & 38 & 53 \\
\hline$n=178$ & $(<7-29)$ & $(<7-37)$ & $(8-53)$ & $(10-77)$ & $(12-142)$ \\
\hline Precocious & & 13 & 15 & 12 & 11 \\
\hline$n=75$ & & $(<7-35)$ & $(<7-38)$ & $(<7-25)$ & $(<7-52)$ \\
\hline \multicolumn{6}{|l|}{ Estradiol $(\mathrm{pg} / \mathrm{ml})$} \\
\hline Normal & 8 & 14 & 30 & 45 & 63 \\
\hline$n=178$ & $(<7-20)$ & $(<7-35)$ & $(7-60)$ & $(12-93)$ & $(12-250)$ \\
\hline Precocious & & 15 & 20 & 23 & 18 \\
\hline$n=75$ & & $(<7-69)$ & $(<7-68)$ & $(8-60)$ & $(<7-117)$ \\
\hline
\end{tabular}

' Data are reported as median (range). $\mathrm{LH}$ : luteinizing hormone; FSH: follicle-stimulating hormone.

${ }^{2}$ Preadolescent girls, excluding the first 2 years of life.

${ }^{3} n$ : number of determinations. 


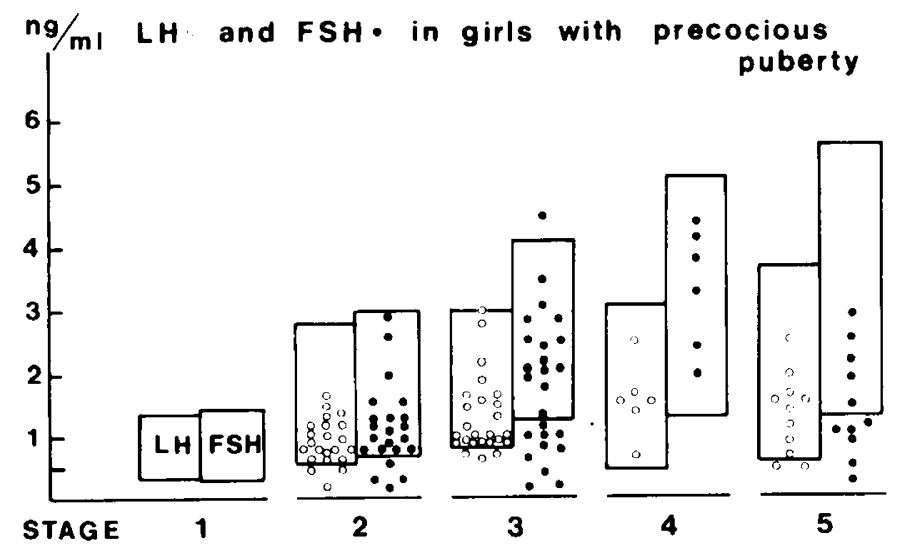

Fig. 3. Plasma luteinizing hormone $(L H)$ and follicle-stimulating hormone $(F S H)$ concentrations in girls with idiopathic precocious puberty grouped according to the stage of sexual development. The columns represent the corresponding normal ranges.

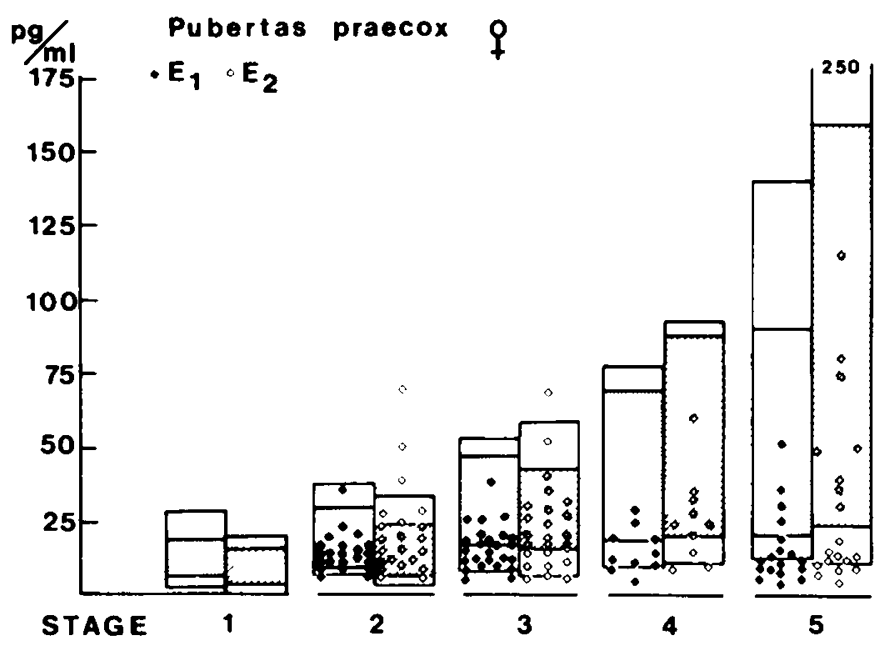

Fig. 4. Plasma estrone $\left(E_{1}\right)$ and estradiol $\left(E_{2}\right)$ concentrations in girls with idiopathic precocious puberty grouped according to the stage of sexual development. The columns represent the corresponding normal ranges (shaded area $=10$ th to 90 th percentile).

pubertal values and values of advanced puberty, showing an almost cyclic pattern. Estrone, however, remained relatively low and showed only minimal variation. Even in a 1.5-year-old sexually precocious girl suffering from a hamartoma of the tuber cinereum, in whom we found a rapid increase of estradiol from prepubertal values to the high values of adult women $(120 \mathrm{pg} /$ $\mathrm{ml}$ ) within 3 weeks, estrone remained fairly stable with only slight elevations (4).

\section{DISCUSSION}

Urinary estrogens of sexually precocious girls were measured by several authors using different methods which were more or less specific. Often estrogen values were found to be elevated (12). Using the chemical method of Brown (7), Bulbrock et al. (10) found abnormally high estrogen excretion in 9 out of 11 patients with precocious or early puberty. Blunck et al. (6) observed pathologically high urine values in six out of seven patients suffering from idiopathic precocious puberty. Since the total number of estrogen determinations in the reported patients is not clear from these publications, we can not judge whether it is more useful to measure estrogens in urine than in plasma in the case of sexual precocity. In our own study a little less than half the estradiol values were above normal for age. Apparently, in idiopathic precocious puberty. ovarian steriods are not se-

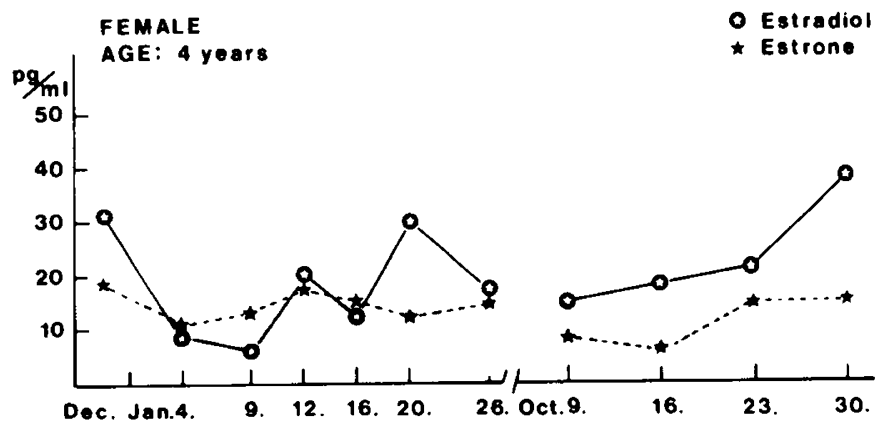

Fig. 5. Plasma estrogens in a 4-year-old girl suffering from idiopathic precocious puberty. The shaded area represents the normal range for estradiol at this age.

creted continuously in elevated amounts. As in normal puberty (30), our patients revealed considerable intraindividual fluctuation of their estradiol levels with high secretory spikes at times. Thus, repeated testing on the same patient increases the chance of observing a pathologic estradiol value in plasma.

Our data on simultaneous determination of gonadotropins and estrogens in plasma fail to demonstrate any concurrence between gonadotropin secretion of the hypophysis and estrogen production of the ovary; however, there is no doubt that in idiopathic precocious puberty the pathologic activity of the ovary depends on increased activity of the hypophysis. Using radioimmunologic techniques several investigators found an elevation of mean gonadotropin values in urine or blood of sexually precocious girls $(5,9,11,17,20,22,24)$, All authors observed a broad overlap of values among healthy prepubertal girls and patients. This is consistent with our finding that only one-third of the $\mathrm{LH}$ levels and one-half of the FSH levels of the patients exceeded the upper normal limit for age.

Job et al. (18) and, more recently, Reiter et al. (23) and Kauli et al. (19) reported that the response of the pituitary gonadotropins to stimulation of exogenous luteinizing hormone-releasing factor (LRF) is more intensive in girls with idiopathic precocious puberty than in normal control subjects. This is not at variance with the fact that in our patients the median values of the gonadotropins were only slightly elevated and not as high as in healthy girls at the same stage of sexual development. In all stages of premature sexual development we observed a considerable variation of gonadotropin levels, and we also found high values, especially when we made repeated measurements on the same patient, indicating that periods of normal prepubertal pituitary gonadotropin secretion alternate with episodes of high gonadotropin release in idiopathic precocious puberty. This gonadotropin release is probably due to an episodic elevation of endogenous LRF activity (27), qualitatively comparable to the stimulus of synthetic LRF in the pituitary function test.

Recently (4) we have shown that even the ovaries of young infants respond to the physiologic gonadotropin elevation of infancy $(13,14)$ and that during the first 2 years estradiol levels in females can be found which are considerably higher than in later prepuberty. It is therefore not surprising that repeated pathologic increase of gonadotropins in childhood leads to maturation of some Graafian follicles which produce more than just basic amounts of estradiol, leading to breast development and other signs of precocious puberty. However, the most surprising finding in our study is the low estrogen levels in the patients compared with those of normal girls at the same developmental stage. In spite of progressive sexual development, the median estradiol values increased only slightly and estrone remained low in the normal prepubertal range. This contrasts considerably with the steep increase of both estradiol and estrone during normal female puberty (Table 1). Apparently transient secretory spikes, as indicated by a few high estradiol values in our patients. are sufficient for saturation of target cell receptors for a certain 
period, thereby inducing and maintaining breast development and changes in vagina and uterus. Perhaps in idiopathic precocious puberty the estrogen receptors are more sensitive or the concentration of sexual hormone-binding globulin is lower than in normal puberty, so that a greater portion of estradiol may reach the receptors even if there is only a relatively slight elevation of total plasma estradiol.

The very low estradiol levels observed in stage 5 can be explained by the fact that 7 of the 9 patients in this group came to our clinic for examination immediately after vaginal bleeding, a condition which, even in adult females, is associated with the lowest estradiol levels.

The different patterns of estrone and estradiol in the patients with true precocious puberty suggest that in these girls there was a precocious maturation mainly of the hypothalamo-hypophyso-gonadal system, leading to periodically increased estradiol production by the ovaries, and that the adrenals, an important source of estrone $(2,8,25,26)$, were less affected.

\section{CONCLUSION}

Plasma levels of LH, FSH, estrone, and estradiol were measured in 34 girls aged from 1 to 9 years and suffering from idiopathic precocious puberty. In some cases values were examined repeatedly at various intervals up to a period of 3 years. Comparison of these data with the hormone levels of healthy girls showed a broad overlap of gonadotropins as well as estrogens among healthy prepubertal girls and patients; thus, most of the patient's LH and estrone values and half of the FSH and estradiol values were found to be normal for age. As in normally maturing girls, considerable intraindividual fluctuations with some high secretory spikes, especially of estradiol, could be observed in idiopathic precocious puberty; however, the median levels of all hormones measured were distinctly lower than those of healthy pubertal girls of the same developmental stage.

\section{REFERENCES AND NOTES}

1. Angsusingha, K., Kenny, F. M., Nankin, H. R., and Taylor, F. H.: Unconjugated estrone, estradiol and $\mathrm{FSH}$ and $\mathrm{LH}$ in prepubertal and pubertal males and females. J. Clin. Endocrinol., 39: 63 (1974).

2. Baird, D. T., Uno, A., and Melby, J. D .: Adrenal secretion of androgens and oestrogens. J. Fendocrinul., 45: 135 (1969).

3. Bidlingmaier, F.. Wagner-Barnack, M., Butenandt, O., and Knorr, D.: Plasma estrogens in childhood and puberty under physiologic and pathologic conditions. Pediat. Res., 7: 901 (1973).

4. Bidlingmaier, F., Versmold, H., and Knorr, D.: Plasma estrogens in newborns and infants. In: M. G. Forest and J. Bertrand: Endocrinologie sexuelle de la période périnatale, p. 299. (INSERM, Paris, 1974).

5. Blizzard, R. M., Johanson, A., Guyda, H., Baghdassarian, A., Raiti, S., and Migeon, C. J.: Recent developments in the study of gonadotropin secretion in adolescence. In: F. P. Heald and W. Hung: Adolescent Endocrinology. p. 1 (Appleton-Century-Crofts, New York, 1970).

6. Blunck, W.. Bierich, J. R., and Bettendorf, G.: Ueber Fruehreife. III Mitteilung. Idiopathische Pubertas praecox, temporaere Fruehreife und praemature Thelarche. Mschr. Kinderheilk., 115: 555 (1967)

7. Brown, J. B.: A chemical method for the determination of oestriol, oestrone and oestradiol in human urine. Biochem. J., 60:185 (1955).

8. Brown, J. B., Falconer, C. W. A., and Strong, J. A.: Urinary estrogen of adrenal origin in women with breast cancer. J. Endocrinol., 19:52 (1956).

9. Buckler, J. M. H., and Clayton, B. E.: Output of luteinizing hormone in urine of normal children and those with advanced sexual development. Arch. Dis. Childhood, 45: 478 (1970).
10. Bulbrook, R. D., Greenwood, F. C., and Snaith, A. H.: Hormone excretion in precocious puberty in girls. Arch. Dis. Childhood, 33: 295 (1958).

11. Butenandt, O., and Souvatzoglu, A.: Luteinisierendes Hormon im Serum gesunder Kinder und bei Pubertas praecox. Mschr. Kinderheilk., I21: 473 (1973).

12. Diczfalusy, E., and Lauritzen, C.: Oestrogene beim Menschen (Springer. Berlin, 1961).

13. Faiman, C., and Winter, J. S. D.: Sex differences in gonadotropin concentrations in infancy. Nature, 232: 130 (1971).

14. Faiman, C., Reyes, F. J., and Winter, J. S. D.: Serum gonadotropin patterns during the perinatal period in man and in the chimpanzee. In: M. G. Forest and J. Bertand: Endocrinologie sexuelle de la période périnatale, p. 281 (INSERM, Paris, 1974).

15. Gupta, D., Attanasio, A., and Raaf, S.: Plasma estrogen and androgen concentrations in children during adolescence. J. Clin. Endocrinol., 40: 636 (1975).

16. Institut National des Radioélements, Belgium.

17. Jenner, M. R., Kelch. R. P., Kaplan, S. L., and Grumbach, M. M.: Hormonal changes in puberty. IV. Plasma estradiol, LH and FSH in prepubertal children, pubertal females, and in precocious puberty, premature thelarche, hypogonadism, and in a child with a feminizing ovarian tumor. J. Clin. Endocrinol., 34: 521 (1972).

18. Job, J. C., Garnier, P. E., Chaussain, J. L., and Canlorbe, P.: Effect of synthetic luteinizing hormone-releasing hormone (LH-RF) on the release of gonadotropins in hypophyso-gonadal disorders of children and adolescents. II. Precocious puberty and premature thelarche. Biomedicine, 19: 77 (1973)

19. Kauli, R., Dickerman, Z., Prager-Lewin, R., and Laron, Z.: LH and FSH response to LH-RH in 27 girls with precocious puberty. Pediat. Res., 9: 677 (1975).

20. Kenny, F. M., Midgley, A. R., Jaffe, R. B., Garces, L. Y., Vazquez, A., and Taylor, F. H.: Radioimmuno assayable serum LH and FSH in girls with sexual precocity, premature thelarche and adrenarche. J. Clin. Endocrinol., 29: 1272 (1969).

21. Marshall, W. A., and Tanner, J. M.: Variations in pattern of pubertal changes in girls. Arch. Dis. Childhood, 44: 291 (1969).

22. Penny, R., Guyda, H. J., Baghadassarian, A., Johanson, A. J., and Blizzard, R. M.: Correlation of serum follicular stimulating hormone (FSH) and luteinizing hormone ( $\mathrm{LH}$ ) as measured by radioimmunoassay in disorders of sexual development. J. Clin. Invest., 49: 1847 (1970).

23. Reiter, E. O., Kaplan, S. L., Conte, F. A., and Grumbach, M. M.: Responsitivity of pituitary gonadotropes to luteinizing hormone-releasing factor in idiopathic precocious puberty, precocious thelarche, precocious adrenarche, and in patients treated with medroxyprogesterone acetate. Pediat. Res., 9: 111 (1975)

24. Root, A. W., Moshang, T., Bongiovanni, A. M., and Eberlein, W. R.: Concentrations of plasma luteinizing hormone in infants, children, and adolescents with normal and abnormal gonadal function. Pediat. Res., 4: $175(1970)$

25. Saez, J. M., Morera, A. M., Dazord, A., and Bertrand, J.: Adrenal and testicular contribution to plasmat oestrogens. J. Endocrinol.. 55: 41 (1972)

26. Saez, J. M., Morera, A. M.: Plasma oestrogens before puberty in human [Abstract]. Acta Paediat. Scand., 62: 84 (1973).

27. Seyler, L. E., and Reichlin, S.: Episodic secretion of luteinizing hormonereleasing factor (LRF) in the human. J. Clin. Endocrinol., 39: 471 (1974).

28. Sizonenko, P. C., Burr, J. M., Kaplan, S. L., and Grumbach, M. M. Hormonal changes in puberty. II. Correlation of serum luteinizing hormone and follicle-stimulating hormone with stages of puberty and bone age in normal girls. Pediat. Res., 4: 36 (1970).

29. Winter, J. S. D., and Faiman, C.: Pituitary-gonadal relations in female children and adolescents. Pediat. Res., 7: 948 (1973)

30. Winter, J. S. D . and Faiman, C.: The development of cyclic pituitary-gonadal function in adolescent females. J. Clin. Endocrinol., 37: 714 (1973).

31. Presented in part at the 14th Annual Meeting of the European Society for Paediatric Endocrinology, Berlin, September, 1975.

32. This research was supported by Deutsche Forschungsgemeinschaft SFB 51 (C) $10)$.

33. Requests for reprints should be addressed to: F. Bidlingmaier, M.D., Universitäts-Kinderklinik Lindwurmstr. 4, D-8000 Munich, West Germany.

34. Received for publication January 19,1976

35. Accepted for publication July 29, 1976. 